\title{
Radu Gyr, de la „cântăreț oficial” al Mișcării Legionare la poetul rezistenței din închisorile comuniste
}

\section{Dan TUDORACHE*}

\begin{abstract}
The poet Radu Gyr is still among the controversial personalities in the collective memory, on the one hand being considered a leading figure of legionary extremism, which does not deserve any posthumous consideration, and on the other hand is considered a hero or even a martyr, due to the moral rectitude showed during the detentions under communism, but especially due to the poems created during all this time, with which he fed the spirit of resistance of thousands of political prisoners. In the present study we have focused our investigation on the biographical periods that feed the two divergent memorial currents, namely the period in which Gyr was a follower of the Legionary Movement and the period in which the poet became one of the most prominent figures of the Romanian communist prisons, in order to verify the argumentative foundations of his supporters and his critics, and in the end we proposed a model of memorial conciliation.
\end{abstract}

Keywords: Radu Gyr, legionary poet, poet of prison resistance, memorial controversy.

\section{O personalitate controversată}

Poetul Radu Gyr este încă o personalitate controversată în memoria colectivă, pe de o parte fiind considerat un personaj de prim plan al extremismului de factură legionară, care nu merită nicio considerațiune postumă, mai ales în spațiul public, iar pe de

\footnotetext{
* Doctorand al Facultății de Istorie, Filosofie și Teologie din cadrul Universității „Dunărea de Jos” din Galați, România.
} 
altă parte este considerat un poet erou sau chiar martir, datorită rectitudinii morale de care a dat dovadă în timpul detențiilor sub comunism, dar mai ales datorită poeziilor create în tot acest timp, și cu care a alimentat spiritul de rezistență a mii de deținuţi politici.

Conflictele memoriale iscate pe seama sa sunt departe de a fi stinse $^{1}$ și credem că acest lucru se datorează atât unui clivaj identitar între susținătorii și contestatarii săi, cât și datorită unei receptări biografice deficitare, păguboasă în mod implicit. Pe scurt, din tabăra contestatară, mai redusă ca impact mediatic, fac parte în special Institutul Naţional pentru Studierea Holocaustului din România „Elie Wiesel” (I.N.S.H.R.E.W.), dar și diverse personalități din lumea politică sau universitară, în special cu vederi politice de stânga.

${ }^{1}$ În anul 2017, o dispută memorială a izbucnit când primăria oraşului Cluj-Napoca a decis ca o mică stradă din cartierul Mănăștur să poarte numele poetului Radu Gyr. Institutul „Elie Wiesel” a reacționat prompt, contestând decizia administrativă. A se vedea mai multe detalii la adresa https://www.stiridecluj.ro/social/numele-strazii-radu-gyr-nu-se-schimba-incaconsilierii-locali-au-dat-inapoi (link accesat la 13.07.2020). Acelaşi institut a reacționat vehement pe pagina sa de Facebook și la începutul lunii ianuarie 2020, față de un articol al istoricului literar Constantin Cubleșan despre viața poetului Radu Gyr, publicat în revista clujeană Tribuna, cu finanțare de la Consiliul local. Reacția a fost însă una insinuantă față de intențiile autorului și opacă față de demonstrația că Gyr a jucat un rol central în rezistența morală a deținuților politici din închisorile românești în perioada anilor 1947-1964. A se vedea https://hi-in.facebook.com/InstitutulElieWiesel/posts/2677900448944264 (link accesat la 13.07.2020). Ulterior, într-un „Raport de monitorizare a antisemitismului”, publicat pe propriul site, Institutul „Elie Wiesel” a avut o apreciere mai nuanțată despre articolul respectiv, afirmând că nu s-a menționat trecutul de lider legionar al lui Gyr, sau faptul că a fost condamnat pentru crime de război. De data aceasta aprecierea ni se pare justă, însă nu imputabilă autorului, întrucât publicistica și poezia ideologică a lui Gyr din perioada ataşamentului față de legionarism este prea puțin cunoscută și accesibilă în latura ei evident violentă și antisemită. De asemenea, din cunoștințele noastre, încă nu există vreun studiu care să demarce o linie între vinovățiile reale și cele manufacturate politic, care au condus la condamnările poetului din anii 1941 și 1945. A se vedea detalii la http://www.inshr-ew.ro/wpcontent/uploads/2020/05/INSHR-EW-Raport-monitorizare-antisemitism.pdf (link accesat la 13.07.2020). 
În tabăra susţinătorilor poetului, se regăsesc, deloc omogen, atât creștini de diferite confesiuni, cât și scriitori, artiști, profesori și jurnaliști, dar și diverse grupuri neo-legionare, ce rezonează atât cu suferința îndelungată a poetului, cât mai ales cu poeziile create în detenție, străbătute de un vibrant mesaj religios.

În ceea ce privește desfășurarea disputelor memoriale, contestatarii impută trecutul legionar al poetului, făcând abstracție totală de rolul pozitiv jucat în spațiul concentraţionar comunist, în timp ce susţinătorii poetului procedează adesea în raport invers faţă de contestatari, punându-i în prim plan calitatea de poet anticomunist și edulcorând rolul jucat în perioada atașamentului față de Mișcarea Legionară. Prin urmare, este clar că avem de-a face cu o receptare biografică selectivă, fiecare tabără acționând în funcție de valorile identitare dominante. Numai că această situație alimentează „un dialog al surzilor", în urma căruia resentimentele reciproce tot sporesc, iar o dezbatere reală, lămuritoare, se lasă încă așteptată.

În plus, deși există numeroase biografii literare alcătuite pe seama poetului, lipsește încă o abordare istoriografică care să dea imaginea de ansamblu a vieții omului Radu Gyr, cu toate suișurile și coborâșurile sale.

Dat fiind că un astfel de studiu ar necesita un spațiu redacțional bogat, în articolul de faţă ne-am concentrat pe acele perioade biografice care alimentează cele două curente memoriale divergente, respectiv perioada în care Gyr a fost adept al Mișcării Legionare și perioada în care a devenit poetul cel mai de seamă al închisorilor comuniste, pentru a verifica fundamentele argumentative ale fiecărei „tabere”, ca în final să propunem un model de conciliere memorială.

\section{Apropierea de Mișcarea Legionară}

Cel care avea să-i creeze iniţial simpatii pentru Mișcarea Legionară a fost scriitorul Nichifor Crainic, în a cărui revistă Gândirea Gyr publica versuri încă din anul 1926². Astfel, spre

2 În autobiografia sa dată Securității, Gyr indică anii 1924-1925 ca perioadă de început a colaborării sale la Gândirea, însă primul număr în care am descoperit 
sfârșitul primăverii anului 1933, într-o convorbire cu Crainic, acesta din urmă îi vorbește cu înflăcărare despre Corneliu Zelea-Codreanu, portretizându-1 la superlativ, „ca pe un tânăr plin de energie, dinamic și incoruptibil, îndrăgostit de țărănime și de neamul românesc", și hotărât să lupte în cadrul mișcării sale ,împotriva corupției și putrefacției, sub toate aspectele ei"’3.

La acea dată Gyr era complet lipsit de orice informație despre Garda de Fier și evoluția acestei mișcări, așa că efectul asupra sa a fost doar de captivare a atenţiei. Însă influența decisivă pentru încadrarea în Mișcarea Legionară o va exercita Mihail Polihroniade, pe care Gyr îl cunoscuse încă din 1932 în redacția revistei „Vremea” și cu care se împrietenise, cucerit de ,temperamentul său jovial și exploziv", dar și de vasta sa cultură în istorie și politică ${ }^{4}$.

Polihroniade îi vorbește cu același entuziasm ca și Crainic despre Corneliu Codreanu, mărturisindu-i că s-a hotărât să adere la mișcarea acestuia, și-i propune lui Gyr să-1 urmeze. Poetul refuză inițial, neînțelegând să fie afiliat politic, dar insistențele lui Polihroniade de a-1 înregimenta și pe Gyr cresc, la fiecare întâlnire vorbindu-i cu aceeași admirație despre Corneliu Codreanu. Îi cere măcar să-1 cunoască, iar Gyr cedează la această doleanță, astfel că în ziua de 8 noiembrie 1933, chiar de sărbătoarea patronului Gărzii de Fier, Sf. Arhanghel Mihail, participă la festivitatea de la Casa Verde ${ }^{5}$, unde mai erau invitați Nichifor Crainic, Dragoș Protopopescu, Nae Ionescu, dar și numeroşi gazetari. În acest context poetul îl cunoaşte pe Corneliu Codreanu, de a cărui personalitate rămâne impresionat ${ }^{6}$.

numele lui Gyr este cel din iulie - septembrie $1926 \mathrm{cu}$ poezia Din ,,chimilituri oltenești”. Gânduri de haiduc, pe lună.... Vezi Gândirea, Anul VI, nr. 6-8, iulie-septembrie 1926, p. 216-218.

3 Arhiva Consiliului Național pentru Studierea Arhivelor Securității, în continuare ACNSAS, fond Informativ, dosar nr. 184933, vol. 5, f. 2.

${ }^{4}$ Ibidem.

5 Casa Verde, situată în cartierul Bucureștii Noi, a fost sediul central al legionarilor, construit din iniţiativa lui Corneliu Codreanu în anul 1933, cu voluntariat din partea legionarilor.

${ }^{6}$ ACNSAS, fond Informativ, dosar nr. 184933, vol. 5, ff. 2-3. 
Radu Gyr, de la „cântăreț oficial” al Mișcării Legionare

la poetul rezistenței din închisorile comuniste

În iarna aceluiași an, gruparea lui Codreanu participă la alegerile parlamentare, iar Gyr este invitat să candideze pe lista organizației chiar de Codreanu, în calitate de prieten ${ }^{7}$. Poetul acceptă propunerea, candidând în județul Muscel, pentru Cameră ${ }^{8}$.

\section{Radicalizarea poetului}

De aici înainte implicarea poetului în Mișcare a devenit din ce în ce mai pasională și s-a desfășurat în cinci direcții, respectiv participarea la ședințe de cuib, crearea de poezii legionare, publicarea de articole social-politice și, pentru o scurtă perioadă, susținerea de conferințe cu substrat ideologic, precum și implicarea în campania alegerilor politice din anul $1937^{9}$.

Într-o primă fază a implicării în legionarism Gyr a activat în cuibul Axa, format de Mihail Polihroniade în jurul revistei cu același nume, apoi în cuibul „Sîn-Medru”, condus de duhovnicul său, preotul Ionescu Duminică, și din 1937 în propriul cuib, „Familia Luminița”. În cadrul activității de cuib, discuțiile se polarizau de cele mai multe ori în jurul doctrinei legionare și a planurilor de a regenera moral societatea românească ${ }^{10}$.

Publicistica sa ideologică reflectă convingerile formate în activitatea de cuib și în contactul cu figurile cele mai proeminente ale Legiunii, iar perioada anilor 1937-1938 a fost cea mai prolifică în acest sens, poetul publicând articole polemice, scrise pe un ton revanșard, radical și chiar antisemit ${ }^{11}$.

Însă ceea ce 1-a consacrat pe Gyr ca figură de prim-plan a Mișcării a fost crearea de poezii şi imnuri mobilizatoare pentru cauza legionară. În acest sens, în perioada anilor 1933-1940, Gyr a

${ }^{7}$ ACNSAS, fond Documentar, dosar nr. 13484, vol. 3, f. 14.

${ }^{8}$ ACNSAS, fond Penal, dosar nr. 14472, vol. 1, ff. 18-19, 33.

${ }^{9}$ ACNSAS, fond Informativ, dosar nr. 184933, vol. 5, ff. 13

${ }^{10}$ ACNSAS, fond Informativ, dosar nr. 184933, vol. 5, ff. 7-11; Ulterior, Familia Luminița s-a extins la 4 cuiburi, totalizând 40 de legionari până în anul 1940 (IDEM, fond Penal, dosar nr. 267, vol. 15, f. 118).

11 ACNSAS, fond Penal, dosar nr. 276, vol. 16, ff. 18-80; IDEM, fond Penal, dosar nr. 14472, vol. 2, ff. 214-216. 
creat aproximativ 20 de astfel de poezii, iar celor mai populare dintre acestea li s-au creat și melodii în colaborare cu compozitorul Ion Mânzatu' ${ }^{12}$.

Dintre toate cântecele intonate în marșurile propagandistice ale legionarilor sau în cadrul ședințelor de cuib, cele create de Radu Gyr erau de departe în topul preferințelor, dându-le ,un avântd deosebit"13, iar cântecul care s-a propagat cel mai mult a fost Sfântă tinerețe legionară, creat în primăvara anului 1936, și devenit în scurt timp imnul Legiunii ${ }^{14}$. Potrivit preotului Nicolae Grebenea, nicio ședință legionară nu se ținea fără a se cânta acest imn ${ }^{15}$. Așa se explică de ce poetul a căpătat faima de „Cântăreţ «oficial» al Gărzii de Fier" $"$.

Câteva dintre creațiile sale propagandistice fac însă o notă distinctă, arătând nu doar atașamentul autorului față de Legiune, ci și gradul său de radicalizare, ținând cont de recursul la violenţă stilizat în rime, respectiv poeziile Sfântă tinerețe legionară, Geme Jilava și Răzbunare.

În Sfântă tinerețe legionară poetul proclama pe de o parte asumarea morții ,,pentru sfânta cruce, pentru țară” și tinerețea dusă pe coordonatele eroismului și al sfințeniei, iar pe de altă parte revendica în final „doar gloanțe pentru trădători”, registrul moral fiind schimbat brusc la 180 de grade $^{17}$.

12 ACNSAS, fond Informativ, dosar nr. 184933, vol. 5, ff. 13, 64.

13 Nicolae GrebeneA, Amintiri din intuneric, Vol. I, București, Edit. Blassco, 2018 , p. 46.

${ }^{14}$ Ion MÂNZATU, Cum am compus cântecele legionare, München, 1996, p. 3-8.

15 Nicolae GREBENEA, op. cit., p. 46.

${ }^{16}$ Valeriu AnANIA, Memorii, Iași, Edit. Polirom, 2008, p. 73.

17 Poezia, deși nu este antisemită, este clar că în acel context îndemna la violență față de cei etichetați drept ,trădători” ai cauzei legionare, indiferent de etnia sau culoarea lor politică, gloanțele pentru ,trădători” fiind în antipod flagrant cu fundamentul creștin de care au făcut caz legionarii. Totodată poezia este în discrepanță nu doar cu morala, ci și cu dogmele creștinismului. De exemplu, moartea este proclamată de poet într-o cheie politică, respectiv ,moarte legionară", doar această coloratură fiind măsura jertfei supreme, însă nu pentru Hristos, asemenea martirilor creștini, ci pentru Corneliu Codreanu, liderul Mișcării Legionare. În afară de Iisus Hristos, modelul central al creștinismului, mai sunt înlocuite și celelalte modele de eroism în credință, 
Radu Gyr, de la „cântăreț oficial” al Mișcării Legionare la poetul rezistenței din închisorile comuniste

Melodia alimentase resentimente care au dezlănţuit violențe şi persecuții, situația creată fiind ,un tragic cerc vicios, din care se părea că nu există ieșire, și unul dintre cei care a plătit mai scump, a fost poetul Radu Gyr"18.

O creație și mai virulentă, cu mesaj cert antisemit, dar cu circulație redusă, a fost poezia Geme Jilava, în care poetul vedea în „neamul lui Iuda” niște asupritori veniți pe pământ românesc, ca în final să proiecteze pornirea la luptă pentru răzbunarea neamului, la comanda lui Codreanu ${ }^{19}$.

De departe însă, creația cea mai virulentă, a fost Răzbunare, cântec conceput în colaborare cu Nelu Mânzatu, la îndemnul lui Vasile Marin, unul din fondatorii Legiunii ${ }^{20}$. În acest cântec, Gyr deplânge soarta neamului său urgisit de asupritori, dar și de „mișei și slugi” care au trădat cauza națională. Pentru aceștia din urmă, refrenul este sentențios, instigând la crimă:

„Pentru trădători, mișei și trădarel Azi vrem gloanțe și vrem ștreang, răzbunare,/ A început vifornița cea mare./ Răzbunare!'"21.

Deși acest cântec a fost oprit de la difuzare în fază incipientă chiar de Corneliu Codreanu, considerându-l violent, totuși el arată

respectiv martirii, de data aceasta cu Nicadorii, asasinii primului ministru I. G. Duca. Din aceste motive, dincolo de forța de convingere a mesajului dată de talentul indubitabil al poetului, prin Sfântă tinerețe legionară Gyr n-a realizat altceva decât să cultive un mesaj eclectic, pseudo-creștin. Derapajele de la dogmele creștinismului colportate de poet în perioada interbelică se regăsesc și în poezia Imnul Căpitanului, în ciuda faptului că legionarii au făcut caz cu sinceritate de creștinism încă de la întemeierea Mișcării. Credem însă că pentru demersul nostru nu mai este necesară o hermeneutică demonstrativă suplimentară în acest sens.

18 Ștefan BACIU, Praful de pe tobă, București, Edit. Eminescu, 1995, p. 497.

${ }_{19}$ Pentru edificare, redăm strofele: „Haite de bestii crude flămânde, / Au năpădit al nostru pământ. / Pui de năpârcă, goniți de oriunde, / Sug trupul Țării sug sânge sfânt! // Secată-i glia, comorile-s furate, / Neamul lui Iuda s-a-mbogățit; / N-avem odihnă, n-avem dreptate, / Neamul lui Iuda ne-a jegmănit”. Radu Gyr, „Geme Jilava”, în Cântece legionare, Sibiu, Serviciul Propagandei Scrise, 1940, p. 75.

${ }^{20}$ Ion MÂNZATU, op. cit., p. 14-15.

21 Radu Gyr, „Răzbunare”, în Cântece legionare, Sibiu, Serviciul Propagandei Scrise, 1940, p. 73. 
nivelul radicalismului la care ajunsese poetul în perioada interbelică ${ }^{22}$.

De altfel, potrivit scriitorului Zaharia Stancu, prieten de condei cu Gyr, acesta din urmă îi considera pe Nicadori și Decemviri drept eroi și sfinți ai cauzei legionare, deși primii îl asasinaseră pe primministrul I. G. Duca în decembrie 1933, iar cei din urmă pe deputatul Mihai Stelescu în iulie 1936, într-un stil extrem de barbar ${ }^{23}$.

Prin urmare, putem spune fără dubii că perioada anilor 19331941, când Gyr a fost atașat cauzei legionare până la fervoare religioasă, rămâne una a rătăcirilor, viața poetului pendulând între radicalismul manifestat în scris şi abuzurile flagrante la care a fost supus pe acest fond de regimul carlist și antonescian.

Este totuși important de reținut că în toată această perioadă Gyr a fost extrem de activ pe tărâm literar, publicând constant poezii, eseuri și cronici literare în periodicele de profil, fără a fi tributar concepțiilor politice, ceea ce a făcut ca producțiile ideologice să fie doar ,un ostrov izolat” în toată opera interbelică ${ }^{24}$. Numai că tocmai imaginea sa de prestigiu din lumea literară, dar și cea de profesor universitar, a dat involuntar autoritate morală derapajelor sale.

\section{3. Între dramatismul social-politic și cel de familie}

De-a lungul timpului, poetul a plătit scump atașamentul față de cauza legionară, prima arestare suferind-o în ultimele zile ale anului 1933, la scurt timp după ce aderase informal la Legiune.

22 Ion MÂNZATU, op. cit., p. 14-15. Ulterior, în timpul scurtei guvernări legionare din septembrie 1940 - ianuarie 1941, cântecul a fost popularizat prin intermediul unor broșuri de cântece și poezii propagandistice.

23 Zaharia Stancu, Zile de lagăr, București, Edit. 1001 Gramar, 2005, p. 275-276. Faptul că Gyr i-a valorizat ca repere morale pe Nicadori reiese voalat și din poezia Sfântă tinerețe legionară: „Sfântă tinerețe legionară, / suim biserici, stăm viteji în închisori, / în prigoana orișicât de-amară / cântăm și ne gândim la Nicadori”. De asemenea, într-o conferință cu iz propagandistic susţinută în prima parte a anului 1936, Gyr i-a descris pe asasinii lui I. G. Duca drept „,arhangheli încălziți la flacăra verde a legionarismului” (ACNSAS, fond Penal, dosar nr. 14472, vol. 2, f. 239).

${ }^{24}$ ACNSAS, fond Informativ, dosar nr. 184933, vol. 5, f. 13. 
Radu Gyr, de la „cântăreț oficial” al Mișcării Legionare

la poetul rezistenței din închisorile comuniste

Arestarea a fost însă scurtă, de numai trei zile, și fiind abuzivă, a avut efectul de a-i alimenta convingerea în justețea cauzei politice la care tocmai aderase ${ }^{25}$.

Un al doilea episod de internare administrativă s-a consumat pe parcursul anului 1938, tot pe fondul poziției deținute în Mișcarea Legionară. Impreună cu alte zeci de figuri de prim plan ale Mișcării, a fost arestat în noaptea de 16 aprilie și închis inițial la Tismana, apoi, de la mijlocul lunii mai până în septembrie în lagărul de la Miercurea Ciuc, după care în lagărul de la Vaslui, până la finele anului $1938^{26}$

Doi ani mai târziu, mai precis în data de 9 februarie 1941, poetul a fost arestat din nou, de data aceasta pentru implicarea în rebeliunea consumată cu o lună în urmă, în cadrul căreia legionarii au intrat în conflict cu armata condusă de mareșalul Ion Antonescu ${ }^{27}$.

În acel context, deținând funcția de director general al Teatrelor Naționale, Operelor Române și Spectacolelor, Gyr a ținut în seara zilei de 22 ianuarie o alocuțiune prin care a făcut un portret moral negativ conducătorului statului și ministrului de justiție, anunțând apoi mulțimea adunată de partea legionarilor în piața Teatrului Naţional, în număr de câteva sute, că este iminentă sosirea generalilor Corneliu Dragalina și Dumitru Coroamă, în sprijinul legionarilor de la București ${ }^{28}$. Numai că în scurt timp lucrurile s-au precipitat, un alt interlocutor a îndemnat manifestanții să ocupe Palatul Telefoanelor, aflat în imediata apropiere, iar aceștia au fost opriți cu rafale de mitralieră în tentativa de a pătrunde în Palat. Pentru acest episod, care s-a soldat și cu câteva decese, Tribunalul Militar al Comandamentului Militar al Capitalei 1-a condamnat pe Gyr, în iunie 1941, la 12 ani de închisoare corecțională $\breve{2}^{29}$. Dacă

25 ACNSAS, fond Documentar, dosar nr. 13484, vol. 3, f. 14; ACNSAS, fond Penal, dosar nr. 14472, vol. 1, ff. 24-25.

${ }^{26}$ Ion MÂNZATU, op. cit., p. 34-37, 40.

${ }^{27}$ ACNSAS, fond Penal, dosar nr. 276, vol. 15, ff. 67, 118, $122 \mathrm{v}$.

${ }^{28}$ ACNSAS, fond Penal, dosar vol. 12, f. 24; IDEM, vol. 15, f. 135, 179, 186-186 v.; IDEM, nr. 276, vol. 16, f. 2 v.

29 În prezent, pe suprafața fostei clădiri a Teatrului Național, distrusă ca urmare a bombardamentelor Aliaților din anul 1944, se află Hotelul Novotel (Dan 
iniţial, pe durata anchetelor, a fost încarcerat la Malmaison, apoi, pe durata desfășurării procesului la Jilava, din iulie până la 7 august 1941 poetul a fost încarcerat în penitenciarul Brașov, dată după care a fost trimis forțat pe front $^{30}$.

După efectuarea instrucției preliminare, timp de aproape două luni a luat parte la dramele războiului consumate pe frontul Odessei, după care, în data de 12 noiembrie, același an, a fost reîncarcerat la penitenciarul Brașov ${ }^{31}$.

În data de 16 martie 1942 a fost din nou încadrat într-o unitate militară pentru retrimitere pe front. De data aceasta însă nu a mai ajuns la destinația finală, întrucât la spitalul de campanie şi triere din Nicolaev a fost declarat inapt, datorită infirmității sale oculare, dar și a altor afecțiuni secundare. Retrimis în țară, a fost reformat definitiv și pus în libertate ${ }^{32}$.

Deși în perioada următoare a stat departe de orice manifestare legionară, în dimineaţa zilei de 26 decembrie 1942, poetul a fost din nou arestat și internat administrativ în lagărul de la Târgu Jiu, până în martie $1943^{33}$.

Pe acest fond de incertitudine socială și detenții repetate, poetul devine din ce în ce mai epuizat sufletește, dar încearcă să-și găsească echilibrul păstrând distanța față de orice activitate politică ${ }^{34}$.

Numai că în toamna anului 1944, în timp ce se afla în orașul Râmnicu Vâlcea, află, prin intermediul unui bun prieten, că urmează să fie din nou internat în lagăr. Perspectiva aceasta devine conflict familial, iar poetul, împovărat moral de eventuala soartă a familiei, clachează psihic şi încearcă să se sinucidă, bând otravă. Este însă salvat și internat în spitalul orașului, suferind de arsuri ale

BRĂTIANU, Martor dintr-o țară încătuşată, București, Fundația Academia Civică, 1996, p. 19-21; ACNSAS, fond Penal, dosar nr. 14472, vol. 2, ff. 2, 211).

${ }^{30}$ ACNSAS, fond Informativ, dosar nr. 184933, vol. 5, f. 56. Cf. Monitorul Oficial

(Partea I), ANUL CIX, nr. 166, 16 iulie 1941, p. 5 (4084).

${ }^{31}$ ACNSAS, fond Penal, dosar nr. 14427, vol. 2, ff. 20, 54, 62.

${ }^{32}$ ACNSAS, fond Informativ, dosar nr. 184933, vol. 5, ff. 53-54.

33 Ibidem, f. 55.

${ }^{34}$ ACNSAS, fond Informativ, dosar nr. 184933, vol. 5, ff. 55-60. 
Radu Gyr, de la „cântăreț oficial” al Mișcării Legionare la poetul rezistenței din închisorile comuniste

tractului respirator, precum şi hemoragii gastrice şi subcutanate intense ${ }^{35}$.

Până la urmă, pe data de 2 octombrie organele poliției locale îi aduc vestea reținerii în lagăr, din dispoziţia Ministerului de Interne. Totuși, deoarece starea sa de sănătate nu permitea transportarea la București, rămâne în continuare în spital până la sfârșitul lunii martie 1945, când, după o ușoară ameliorare, este transportat cu escortă în arestul Prefecturii Poliției Capitalei ${ }^{36}$.

Între timp, printr-un Jurnal al Consiliului de Miniștri din ianuarie 1945, Gyr a fost introdus pe o listă cu 64 de persoane bănuite a fi responsabile de dezastrul țării, în frunte cu mareșalul Ion Antonescu și miniștrii din guvernarea sa. Acesta era doar unul dintre primii pași pe care comuniștii i-au întreprins pentru epurarea și lichidarea elitei politice interbelice, sub pretextul defascizării țării. Prin urmare, poetul a fost judecat într-un lot al ziariștilor cu vederi de dreapta și extremă dreapta, deci anticomuniști fermi, care pledaseră în publicistica lor pentru justețea războiului cu Rusia Sovietică ${ }^{37}$.

În cadrul procesului, Gyr a fost acuzat că prin întreaga activitate legionară desfășurată între anii 1933-1941, dar și prin publicistica anticomunistă din anii 1943-1944, s-ar fi pus în slujba fascismului și hitlerismului. Drept urmare, în data de 4 iunie 1945 Tribunalul Poporului 1-a condamnat la 12 ani detenție riguroasă și confiscarea întregii averi, ,pentru crima de dezastrul țării prin săvârșirea de crime de război”" ${ }^{38}$.

Pentru că sănătatea îi era iarăşi în pericol, după proces a fost transferat la penitenciarul Văcărești, iar din februarie 1946 la Penitenciarul Brașov, unde a rămas până în iulie $1947^{39}$.

În acest timp, suferința închisorii a devenit motiv de inspirație pentru poezii de mare sensibilitate, poetul reuşind să

35 Ibidem, f. 61; Valeriu Anania, op. cit., p. 88.

36 ACNSAS, fond Informativ, dosar nr. 184933, vol. 5, f. 62.

37 Emil Rus, Delictul de opinie: Procesul ziariștilor 1945, București, Institutul Național pentru Studiul Totalitarismului, 2012, p. 41-43, 105-124.

${ }^{38}$ Ibidem, p. 212, 231-234, 240.

${ }^{39}$ ACNSAS, fond Informativ, dosar nr. 184933, vol. 5, f. 65. 
creeze aproximativ 45 de poezii cu tematică carcerală ${ }^{40}$, pe care le-a transcris într-un caiet, întrucât obținuse dreptul de a avea materiale de scris din partea Direcției Penitenciarelor, cu condiția de a scrie „democratic”, și cu verificarea tuturor scrierilor ${ }^{41}$.

\section{Poetul rezistenței din închisorile comuniste}

În iulie 1947 Gyr a fost transferat cu caietul său de poezii la penitenciarul Aiud, măsura dovedindu-se a fi de însemnătate crucială pentru destinul său și a altor mii de întemnițați ${ }^{42}$. Fostul deținut politic Nicolae Grebenea, avea să-și amintească astfel primul contract cu poetul, odată sosit în Aiud: ,firav, cu o afecțiune la intestine, foarte cult, tăcut și discret, atent cu toată lumea. In toți anii mei de inchisoare n-am cunoscut vreun om mai politicos ca dânsul. Era un punct de atracție. Senin și blând, abordabil de oricine, împrăștia în jur un aer de sănătate morală, de încredere și bărbăție. Venea de la spitalul din Brașov. [...] Era încă în plină vervă creatoare și apărea mereu cu ceva nou. Creația lui variată a fost ca o hrană pentru toți, ca o cuminecătură la praznicele mari" ${ }^{43}$.

Din acest moment, creația lui Gyr începe să joace un rol din ce în ce mai important pentru rezistența morală a deținuţilor politici, constrânși la un regim extrem de dur începând cu toamna anului 1948.

Pe acest fond, de înăsprire dramatică a condițiilor de încarcerare, poeziile lui Gyr create anterior în penitenciarele

${ }^{40}$ Gyr și-a grupat poeziile create la Văcărești și Brașov între anii 1945-1947 întrun ciclu intitulat „Sângele temniței”, iar în această perioadă a avut câteva încercări de a le scoate din penitenciar (ACNSAS, fond Documentar, dosar nr. 10160, vol. 2, f. 156.). Una dintre ele s-a desfăşurat cu ocazia unui vorbitor cu familia, poetul reușind să transmită cu acea ocazie zeci de poezii (ACNSAS, fond Informativ, dosar nr. 184933, vol. 2, ff. 140-141). Ele au fost publicate postum, prin grija fiicei, în primul său volum de poezii carcerale, cu subtitlul dat de poet în timpul detenției (Radu Grr, Poezii I. Sângele temniței. Balade, Timişoara, Edit. Marineasa, 1992, p. 9-118).

${ }^{41}$ ACNSAS, fond Penal, dosar nr. 14472, vol. 2, f. 156;

${ }^{42}$ ACNSAS, fond Informativ, dosar nr. 184933, vol. 5, f. 65.

${ }^{43}$ Nicolae GreBEnEA, op. cit., p. 140-141. 
Radu Gyr, de la „cântăreț oficial” al Mișcării Legionare

la poetul rezistenței din închisorile comuniste

Văcărești și Brașov s-au răspândit rapid atât pe cale orală, cât și scrise cu mijloace improvizate. La fel s-au răspândit și cele proaspăt create, iar într-o măsură mai mică cele create și publicate în periodicele din perioada interbelică.

Popularizarea creațiilor de închisoare s-a desfăşurat în trei etape, prima dintre ele consumându-se în rândul intelectualilor și ofițerilor superiori, încarcerați în secția destinată „,criminalilor de război și vinovaţi de dezastrul țării”, acolo unde a fost închis și Gyr până în iunie $1949^{44}$. În această fază, răspândirea poeziilor s-a făcut cu ajutorul caietului său de poezii, cu care venise din Penitenciarul Brașov, și care, până la confiscarea survenită în toamna anului 1948, număra aproximativ 60-70 de poezii ${ }^{45}$. Unul dintre difuzorii cheie din această perioadă a fost chiar filosoful Mircea Vulcănescu, coleg de celulă cu Gyr, și care grație unei memorii fabuloase, i-a învățat aproape toate poeziile din caiet ${ }^{46}$.

O a doua etapă a fost răspândirea poeziilor în rândul legionarilor încarcerați la Aiud pe Celular, etapă care a luat amploare pe parcursul anilor 1948-1950, fie cu ajutorul fundurilor de gamelă unse cu emulsie de apă, săpun și praf D.D.T., fie prin scrierea pe pereții celulelor ${ }^{47}$.

Și în fine, o a treia etapă a fost aceea a răspândirii poeziilor sale în celelalte penitenciare și lagăre din țară, la restul masei de deținuți politici, indiferent de orientarea politică a acestora ${ }^{48}$. În această fază, răspândirea poeziilor s-a făcut atât sub forma orală sau scrisă prin diverse mijloace improvizate de deținuți, cât și prin intermediul limbajului Morse bătut în pereți sau țeava caloriferului. La fel circulau și poeziile carcerale ale altor poeți, cum a fost cazul celor create de Nichifor Crainic, Andrei Ciurunga, Sergiu Mandinescu ori Aurel Dragodan, însă cele ale lui Gyr erau de

${ }^{44}$ ACNSAS, fond Informativ, dosar nr. 184933, vol. 5, f. 65.

${ }^{45}$ ACNSAS, fond Penal, dosar nr. 276, vol. 5, ff. 430-431.

${ }^{46}$ ACNSAS, fond Informativ, dosar nr. 184933, vol. 5, f. 74.

${ }^{47}$ Nicolae TrIFOIU, Pagini literare. Amintiri și evocări, Cluj-Napoca, Edit. Napoca Star, 2001, p. 172.

${ }^{48}$ ACNSAS, fond Informativ, dosar nr. 184933, vol. 2, f. 83. 
departe cele mai populare ${ }^{49}$. In acest sens, fostul deținut politic Ioan Ianolide aprecia în memoriile sale că ,toată suflarea românească se regăsea în poezia lui. Ea a constituit factorul ideologic al rezistenței românești, a fost în același timp mesajul nostru, strigătul nostru de disperare și descrierea crudei realități dar mai presus de toate a fost forța credinței și afirmării noastre" $" 50$.

În același registru, scriitorul Hans Bergel, arestat și el în repetate rânduri, avea să rememoreze că ,de-a lungul anilor mei de detenție am auzit sute de poezii ale lui Radu Gyr. Cu niciun alt poet român nu m-am întâlnit de atunci mai des decât cu Radu Gyr, care ajunsese să orbească în închisoare. Când se întâmpla să vină cineva din altă temniță cu o poezie de Radu Gyr, îl ascultam cuprinși de emoție: eram studenți, păstori, profesori, țigani, negustori, ofițeri, artiști, ingineri...

Ceream parcă înfometați, încă o dată și încă o dată până când învățam noua poezie pe de rost. Mii de oameni dintre cei intemnițați [...] trăiau cu și din poeziile lui Radu Gyr. N-a existat nicio închisoare și niciun lagăr pe unde să fi trecut poetul și unde poeziile lui să nu circule din gură în gură. Erau poezii încărcate de suflul rezistenței care ne anima pe toți. In conștiința noastrăa, a deținuților, Radu Gyr devenea, cu fiecare nouă poezie, un mit. El era un Orfeu al nostru care, în nopțile de izolare, în frigul din cazematele subterane, fără vreo unealtă de scris, fără un vârf de creion, fără prieteni, imprima poeziilor sale o melancolie eroică, un dram de speranță în libertate precum și un spirit de frondă, un curaj combativ inainte de a trimite mesaje în lumea de dincolo de ziduri și de sârmă ghimpată" ${ }^{\prime 5}$.

Într-adevăr, în poeziile sale de închisoare Gyr a redat experiența recluziunii într-o gamă largă de convulsii sufletești: poetul crede și speră, apoi disperă, ca tot el să stea ,tare, tare ca un

49 Constantin Ticu Dumitrescu, Mărturie și document, Vol. I, Partea a III-a, Iași, Edit. Polirom, 2008, p. 304-305.

${ }^{50}$ Ioan IANOLIDE, Intoarcerea la Hristos. Document pentru o lume nouă, ediția a II-a, ediție îngrijită la Mănăstirea Diaconești, București, Edit. Bonifaciu, 2012, p. 300.

${ }^{51}$ Hans Bergel, Intoarcerea lui Ulise. Eseuri, Braşov, Edit. Arania, 1995, p. 11-13. 
Radu Gyr, de la ,cântăreț oficial” al Mișcării Legionare la poetul rezistenței din închisorile comuniste

crez"52. El își urlă setea de libertate ca nimeni altul, detestând cu înverșunare lanțurile, zăbrelele și zidurile pușcăriei ${ }^{53}$, și tot el se răzvrătește față de Dumnezeu din cauza destinului nedrept ${ }^{54}$, apoi îl trage la răspundere ${ }^{55}$, cerându-I dreptul de a-și urî asupritoriii ${ }^{56}$, ca în final să ajungă la împăcare cu $\mathrm{El}^{57}$, și la transfigurare sufletească ${ }^{58}$ : „Doamne, fă din suferință / pod de aur, pod înalt. / Fă din lacrimă velință / ca-ntr-un pat adânc și cald. // Din lovirile nedrepte / faguri facă-se și vin. / Din înfrângeri, scări și trepte, / din căderi urcuş alpin" "59.

În alte creatii carcerale, Gyr proiectează imagini angelice tot atât de pasional cum își transpune răbufnirea instinctelor și a dorurilor de cei dragi ${ }^{60}$, sau împletește în contraste antagonice imaginile paradisiace ale copilăriei cu cele brutale ale pușcăriei ${ }^{61}$, iar agonia suferinței o contrastează cu pofte aprige de viață ${ }^{62}$. Pe scurt, Gyr așterne în poeziile

52 A se vedea poeziile Ce tare sunt, Doamne, Renunțări (Radu GYR, Poezii II. Stigmate, Edit. Marineasa, 1933, p. 72-73, 77-78), și Crezul (Aurelian POPESCU, Poezia în cătușe, Craiova, Edit. Omniscop, 1995, p. 21).

53 A se vedea poeziile Zăbrele, Jind, Lanțuri, Libertate, Când voi muri, 281, Cântec de hoț (Radu GYr, Poezii I. Sângele temniței. Balade, Timișoara, Edit. Marineasa, 1992, p. 104-105), și Aiudule, Aiudule (Radu Gyr, Poezii III. Lirica orală, Timişoara, Edit. Marinasa, 1994, p. 35).

54 A se vedea poeziile Osândă, Nostalgie, Crunt m-am invierşunat, Impuritate, Darul cel crâncen și Identitate (Radu GYr, Poezii II. Stigmate, Timişoara, Edit. Marineasa, 1993, p. 74-76, 87-90, 112, 214-216, 236).

55 A se vedea poezia La judecata din urmă (Ibidem, p. 27).

${ }^{56}$ A se vedea poezia Cântec de ură (Radu Grr, Poezii I. Sângele temniței. Balade, Timișoara, Edit. Marineasa, 1992, p. 89-91).

57 A se vedea poezia Impăcare (Radu GYR, Poezii II. Stigmate, Timișoara, Edit. Marineasa, 1993, p. 171-173).

58 A se vedea poeziile Rugă, Sunt, Doamne, copt pentru cules și Metanie în (Radu GyR, Poezii III. Lirica orală, Timișoara, Edit. Marineasa, 1994, p. 33-34, 3839, 45).

${ }^{59}$ A se vedea poezia Metanie (Ibidem, p. 45).

${ }^{60}$ A se vedea Ad uxorem, (Ibidem, p. 81).

61 A se vedea poezia Vorbitor (Radu Gyr, Poezii I. Sângele temniței. Balade, Timişoara, Edit. Marineasa, 1992, p. 47-49).

${ }^{62}$ A se vedea poeziile Cântec de nuntă (Ibidem, p. 54-55), Vin amintirile, Cântec de venin și De-ar mai țâşni în drum fericirea (Radu Gyr, Poezii II. Stigmate, Timişoara, Edit. Marineasa, 1993, p. 120, 225) 
sale ,toată sbaterea și toată măcinarea interioară a condamnatului”, cu o sensibilitate şi pasiune electrizantă ${ }^{63}$.

De aceea, având aceste calităţi şi această largă deschidere umană, trecutul său politic era ignorat de către deținuții nelegionari, şi nu constituia o piedică pentru răspândirea poeziilor sale carcerale ${ }^{64}$.

Mai mult decât atât, ,pentru deținuții politici români, de diferite nuanţe politice, Radu Gyr nu era un poet legionar, ci un poet al tuturor celor oprimați în închisori" ${ }^{65}$, ba chiar era văzut ca „o lumină [...] pentru întreg neamul românesc" "66.

Dar în acelaşi timp Gyr s-a dovedit a fi și un experimentat animator de mase, concepând numeroase poezii cu care a îndemnat permanent la rezistență comunitară sau individuală faţă de suferința recluziunii și artizanii ei. Așa se explică apetența deținuților politici pentru zecile sale de poezii mobilizatoare, precum Jnepii, Cântec de luptă, Ridică-te, Gheorghe, ridică-te, Ioane!, sau celebrul colind A venit și-aici Crăciunul, care a devenit piesă de rezistență la celebrarea anuală a marelui praznic creștin ${ }^{67}$. Pe de altă parte, pe lângă poeziile sale, Radu Gyr se bucura în lumea deținuților politici și de o imagine fără reproș. Blând, afabil, cult și modest în același timp, cu un simț al umorului pe care îl manifesta nedisimulat chiar și în cele mai grele încercări, poetul a devenit cu timpul un om legendar ${ }^{68}$.

${ }^{63}$ ACNSAS, fond Informativ, dosar nr. 184933, vol. 5, f. 52.

${ }^{64}$ Cosmin BudEANCĂ (coord.), Experiențe carcerale în România comunistă, Vol. VI, Iaşi, Edit. Polirom, 2012, p. 261.

65 Remus Radina, Testamentul din morgă , București, Edit. Criterion Publishing, 2010, p. 96.

66 Octavian VoINEA, Masacrarea studențimii române în închisorile de la Pitești, Gherla şi Aiud, ediție îngrijită de Gheorghe Andreica, București, Edit. Majadahonda, 1996, p. 177-180.

${ }^{67}$ A se vedea poeziile Jnepii, Cântec de luptă, Cântec deplin, Ridică-te, Gheorghe, ridică-te, Ioane!, Ințeleptul (Radu GYR, Poezii III. Lirica orală, Timișoara, Edit. Marineasa, 1994, p. 27-28, 44, 64, 79-80, 95), Ca bozia, Cavalcadă, Victorii negre, Ce tare sunt, Doamne, Nu-mi pun credința, Ofrande (Radu GYR, Poezii II. Stigmate, Timișoara, Edit. Marineasa, 1993, p. 17, 57-58, 70-71, 72-73, 168, 254), Crezul şi Tăcem din gură (Aurelian POPESCU, op. cit., p. 32).

68 Gabriel BăLĂNESCU, Din împărăția morții. Cronică rezumată din închisori, Madrid, Edit. Dacia, 1981, p. 407-415; Nicolae GREBENEA, op. cit., p. 140-141; Ioan IANOLIDE, op. cit., p. 300-305. 
Radu Gyr, de la „cântăreț oficial” al Mișcării Legionare

la poetul rezistenței din închisorile comuniste

Prin urmare, dincolo de radicalismul manifestat în publicistica și poezia ideologică din anii tinereții, este cert că opera de închisoare și rectitudinea morală manifestată constant în calitate de condamnat politic, îl consacră drept una dintre cele mai reprezentative figuri ale rezistenței din pușcăriile comuniste.

In plus, condamnarea la moarte pe care autoritățile comuniste i-au dat-o în anul 1959 pentru toate poeziile create până atunci în detenție, $\mathrm{i}$-a adus poetului și aureola de martir ${ }^{69}$.

\section{5. Încercare de conciliere memorială}

T,inând cont de acest traseu biografic, este clar că avem de-a face cu o persoană care s-a manifestat diferit, în contexte diferite. Pe de o parte avem un Radu Gyr, militant radicalizat al legionarismului, iar pe de altă parte un Radu Gyr cuminte, delicat și dârz deopotrivă, aşezat în matricea gândirii creștine. Tot acest drum, de la „cântărețul oficial al Gărzii de Fier” până la cel de

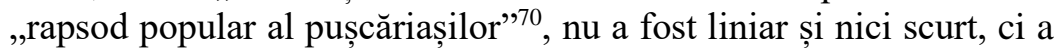
fost marcat de numeroase frământări sufletești, crize de conștiință și prefaceri interioare, petrecute pe fondul unor situații extreme: detenții repetate, deziluzii profunde, război, incertitudine socială, depresie și tentativă de suicid și iarăși îndelungă detenție. În acest sens, poeziile create sunt oglinda morală a trecerii sale prin timp, dacă le contextualizăm și le decelăm mesajul etic în ordine cronologică. Aceasta este cheia sesizării transformărilor sale interioare și întreaga operă poetică demonstrează fără echivoc că Gyr a fost o personalitate complexă, care nu poate fi receptată întrun registru moral monocrom, fie el imaculat sau indezirabil.

69 Deși prin numeroasele articole biografice care se găsesc în spațiul online s-a vehiculat intens ideea că Gyr a fost condamnat la moarte pentru poezia manifest Ridică-te, Gheorghe, ridică-te Ioane!, în realitate condamnarea a fost pronunțată pentru întreaga activitate poetică desfăşurată în detenția din anii 1945-1956 (ACNSAS, fond Penal, dosar nr. 276, vol. 10, f. 264-265, 274-278, 288 v.-290).

70 Petre PANDREA, Memoriile mandarinului valah, Vol. I: Jurnal 1954-1956, București, Edit. Vremea, 2011, p. 407. 
Prin urmare, orice receptare memorială onestă ar trebui să țină cont de ambele ipostaze ale poetului.

Totuși, fără a-i oculta concepțiile radicale și erorile politice din perioada interbelică, opinăm că rolul de catalizator moral pe care 1-a avut în timpul detențiilor politice sub comunism prevalează asupra aspectelor negative din timpul implicării sale în legionarism, atât ca durată de timp, cât și ca impact social.

Conștienți că în ciuda acestui demers de conciliere memorială suntem departe de a stinge controversele stârnite pe seama poetului, propunem totuși poziția scriitorului și fostului deținut politic Hans Bergel, considerând-o cea mai echilibrată soluție de receptare a poetului pentru prezent: „Nu mi-a păsat mie, care sânt neamț crescut cu poezia germană, adică cu Goethe, Kleist și Schiller, de concepțiile lui politice: Gyr a însemnat pentru mine un sprijin moral, poezia lui m-a ajutat să supraviețuiesc, nu fiindcă era poezie română, ci fiindcă ajungea până și în inima mea nemțească. Peste tot, în toate închisorile pe unde am stat, am intâlnit poezii de Gyr și din cauza asta - indiferent de ce orientare politică a avut - eu îl iert pentru tot ce a făcut el înainte. Poezia lui Gyr a însemnat pentru sute și mii de oameni din detenție singurul mod de a supraviețiu "71.

$\cos 8$

\section{Bibliografie}

1. Arhiva Consiliului Naţional pentru Studierea Arhivelor Securității (ACNSAS), fond Documentar, dosar nr. 13484, vol. 3.

2. ACNSAS, fond Documentar, dosar nr. 10160, vol. 2.

3. ACNSAS, fond Informativ, dosar nr. 184933, vol. 2, 5.

4. ACNSAS, fond Penal, dosar nr. 14472, vol. 1-2.

5. ACNSAS, fond Penal, dosar nr. 267, vol. 12, 15-16.

6. Cântece legionare, Sibiu, Serviciul Propagandei Scrise, 1940.

${ }^{71}$ Hans BERGEL, „Întâlnirea cu civilizația și cultura română a fost decisivă pentru tot restul vieții mele" în Contrafort, nr. 9-11 (83-85), septembrie-noiembrie 2001. Articol disponibil online la http://www.contrafort.md/old/2001/8385/246_3.html (accesat la 30.11.2018) 
Radu Gyr, de la ,cântăreț oficial” al Mișcării Legionare la poetul rezistenței din închisorile comuniste

7. AnANia, Valeriu, Memorii, Iași, Edit. Polirom, 2008.

8. BACIU, Ștefan, Praful de pe tobă, București, Edit. Eminescu, 1995.

9. BĂLĂNESCU, Gabriel, Din împărăția morții. Cronică rezumată din inchisori, Madrid, Edit. Dacia, 1981.

10. Bergel, Hans, Intoarcerea lui Ulise. Eseuri, Brașov, Edit. Arania, 1995.

11. BRĂTIANU, Dan, Martor dintr-o țară încătușată, București, Fundația Academia Civică, 1996.

12. BudEANCĂ, Cosmin (coord.), Experiențe carcerale în România comunistă, Vol. I, Iași, Edit. Polirom, 2007.

13. IDEM, Experiențe carcerale în România comunistă, Vol. VI, Iași, Edit. Polirom, 2012.

14. Dumitrescu, Constantin Ticu, Mărturie și document, Vol. I, Partea a III- $a$, Iaşi, Edit. Polirom, 2008.

15. GYr, Radu, Poezii I. Sângele temniței. Balade, Timișoara, Edit. Marineasa, 1992.

16. IDEM, Poezii II. Stigmate, Timișoara, Edit. Marineasa, 1993.

17. IDEM, Poezii III. Lirica orală, Timișoara, Edit. Marineasa, 1994.

18. GrebenEA, Nicolae, Amintiri din intuneric, Vol. I, București, Edit. Blassco, 2018.

19. IANOLIDE, Ioan, Intoarcerea la Hristos. Document pentru o lume nouă, ediția a II-a, ediție îngrijită la Mănăstirea Diaconești, București, Edit. Bonifaciu, 2012.

20. MÂNZATU, Ion, Cum am compus cântecele legionare, München, 1996.

21. PANDREA, Petre, Memoriile mandarinului valah, Vol. I: Jurnal 1954-1956, București, Edit. Vremea, 2011.

22. POPESCU, Aurelian, Poezia în cătușe, Craiova, Edit. Omniscop, 1995.

23. RADINA, Remus, Testamentul din morgă, București, Edit. Criterion Publishing, 2010.

24. Rus, Emil, Delictul de opinie: Procesul ziariștilor 1945, București, Institutul Naţional pentru Studiul Totalitarismului, 2012.

25. StANCU, Zaharia, Zile de lagăr, București, Edit. 1001 Gramar, 2005.

26. Trifolu, Nicolae, Pagini literare. Amintiri și evocări, ClujNapoca, Edit. Napoca Star, 2001. 
27. VoINEA, Octavian, Masacrarea studențimii române în închisorile de la Pitești, Gherla şi Aiud, ediție îngrijită de Gheorghe Andreica, București, Edit. Majadahonda, 1996.

\section{Website-uri}

28. http://www.contrafort.md/old/2001/83-85/246_3.html.

29. https://hiin.facebook.com/InstitutulElieWiesel/posts/2677900448944264

30. http://www.inshr-ew.ro/wp-content/uploads/2020/05/INSHREW-Raport-monitorizare-antisemitism.pdf

31. https://www.stiridecluj.ro/social/numele-strazii-radu-gyr-nu-seschimba-inca-consilierii-locali-au-dat-inapoi 